\title{
Tomato Spotted Wilt Virus Resistance in Chrysanthemum Expressing the Viral Nucleocapsid Gene
}

John M. Sherman, James W. Moyer, and Margaret E. Daub, Department of Plant Pathology, Box 7616, North Carolina State University, Raleigh 27695-7616

\begin{abstract}
Sherman, J. M., Moyer, J. W., and Daub, M. E. 1998. Tomato spotted wilt virus resistance in chrysanthemum expressing the viral nucleocapsid gene. Plant Dis. 82:407-414.

Three tomato spotted wilt virus (TSWV) nucleocapsid (N) gene constructs were employed for Agrobacterium-mediated transformation of chrysanthemum (Dendranthema grandiflora) cv. Polaris. These constructs contained either a full-length $\mathrm{N}$ gene (pTSWVN+), a full-length $\mathrm{N}$ gene encoding a truncated $\mathrm{N}$ protein (pTSWVNt), or an antisense version of the full-length $\mathrm{N}$ gene (pTSWVN-), all derived from a dahlia isolate of TSWV (TSWV-D). Initial resistance screens were conducted on cuttings made from 152 pTSWVN+, 37 pTSWVNt, and 47 pTSWVN- transformed plants employing a highly virulent, heterologous strain of TSWV (TSWV-GB) isolated from chrysanthemum and vectored by thrips. This screening served to eliminate the majority of TSWV-susceptible transgenic lines. More rigorous resistance tests with three rounds of mechanical inoculation with TSWV-GB identified one pTSWVNt and two pTSWVN- transformed lines that exhibited a total lack of systemic symptoms and no virus accumulation. Six other lines, including some pTSWVN+, exhibited a lack of one or more of the destructive necrotic TSWV symptoms (stem canker and apical bud death) and a delay in symptom expression. Both sense and antisense constructs, therefore, were found to be effective at yielding TSWV resistance in chrysanthemum. Molecular analysis revealed that the highly TSWV-resistant pTSWVNt line had no detectable levels of N protein. All three resistant lines had low levels of $\mathrm{N}$ gene transcript and at least three transgene insertion sites within their genomes, although susceptible lines often had a similar number of insertion sites. The generation of Polaris lines resistant to TSWV transmitted either mechanically or by thrips represents the first time a major ornamental crop has been genetically engineered for disease resistance.
\end{abstract}

Additional keywords: floral crop biotechnology

Tomato spotted wilt tospovirus (TSWV) is the type member of the Tospovirus genus in the family Bunyaviridae. This virus has one of the widest host ranges of any plant virus, infecting over 600 species of plants in more than 50 families, including both monocots and dicots $(4,10)$. TSWV has several unusual characteristics for a plant virus, including an ambisense genome organization, quasispherical enveloped virions, and transmission by thrips (35).

TSWV is a major disease threat to the U.S. floral industry and is known to infect 41 greenhouse ornamentals (18). Movement of one of its vectors, the western flower thrips (Frankliniella occidentalis), is believed to be a major reason for the virus's increasing importance (28). Epidemics of TSWV on Dahlia, Lycopersicon, Sinningia, and Tagetes spp. in commercial greenhouses in Canada have been documented and linked to populations of the

Corresponding author: Margaret E. Daub

E-mail: margaret_daub@ncsu.edu

Accepted for publication 19 December 1997.

Publication no. D-1998-0130-02R

(C) 1998 The American Phytopathological Society vector (1). TSWV has become such an important pathogen in greenhouses that Pennsylvania banned entry of any TSWVinfected plants into the state (18). TSWV represents the first virus disease for which such stringent measures have been implemented.

Chrysanthemum, Dendranthema grandiflora Tzvlev, is one ornamental crop devastated by TSWV. Symptomatology is highly variable and cultivar dependent. Most commonly, chlorotic spots and foliar necrosis are observed, with leaf bronzing, chlorotic ring and line patterns, internal necrosis, stem cankers, and stunting occurring less frequently. Symptomless infection may occur and is of importance because stock plants are customarily maintained for long periods as sources of cuttings (28).

TSWV control is often difficult. Thrips eradication is rarely successful owing to their small size and the development of insecticide resistance by this vector $(1,18)$. The large genome size and polyploidy (hexaploid) of chrysanthemum makes the identification and isolation of any naturally occurring resistance genes very difficult $(13,42)$. Furthermore, the overriding importance of ornamental traits such as flower color and morphology, productivity, and vase life and the rapid turnover in cul- tivar popularity has hampered the development of TSWV resistance in chrysanthemum (13). Genetic engineering with pathogen-derived genes provides an additional strategy for TSWV control (9).

The first report of plants genetically engineered with a tospovirus nucleocapsid (N) gene was by Gielen et al. (15) with tobacco. Other groups working independently have also obtained plants expressing the $\mathrm{N}$ gene of TSWV that show resistance to the virus $(11,20,27,31-34,36,39,41)$. All but one of these reports of resistance (32), however, have been with tobacco or tomato, both members of the transformationamenable Solanaceous family. Further, some of these studies chose to identify as "resistant," lines with as few as 20 to $50 \%$ of plants lacking systemic symptoms $(11,20,39)$, a level unacceptable for deployment of these plants for practical disease control.

The goal of this work was to investigate the utility of pathogen-derived resistance for the development of horticulturally acceptable levels of TSWV resistance in chrysanthemum. Use of a recently developed transformation system for chrysanthemum (37) allowed us to transfer TSWV genes into this economically valuable crop. In this paper, we report the generation of plants of cultivar Polaris, a highly TSWVsusceptible and economically important cut-flower chrysanthemum, that are completely protected against TSWV infection and others that are resistant to the damaging necrotic symptoms of the disease. In addition, we describe a screening method that allows for efficient identification of resistant plants from the majority of transformed plants which lack resistance.

\section{MATERIALS AND METHODS}

Plant material. The cultivar Polaris is a white cut-flower chrysanthemum that is economically important and highly susceptible to TSWV (28). Plants were propagated by cuttings and were maintained in a greenhouse with continuous supplemental fluorescent illumination that maintained the plants in a vegetative state.

TSWV N gene cloning. The region of the TSWV small RNA (12) containing the $\mathrm{N}$ gene (nucleotides [nt] 1,983 to 2,767 ) was amplified by reverse transcriptasepolymerase chain reaction (RT-PCR) by the methods of Ausubel et al. (3). Template viral RNA was purified by the methods of Law et al. (23) from an isolate of TSWV 
(TSWV-D) originally isolated from dahlia plants. The amplification products were cloned into the plasmid Bluescript SK (Stratagene, La Jolla, CA) and verified by hybridization with viral RNA as described by Law et al. (24). The genes were then subcloned into the XbaI-BamHI site of the transformation vector $\mathrm{pBI} 121$ (Clontech Laboratories, Palo Alto, CA). The resulting plasmids (pTSWVN+, TSWVNt, and pTSWVN-) (Fig. 1) were maintained in Escherichia coli $\mathrm{DH} 5 \alpha$ cells.

Sequencing (DNA Sequencing Facility, Iowa State University, Ames) of the engineered constructs demonstrated that the $\mathrm{N}$ gene in pTSWVNt had a PCR-produced error (an additional $G$ at nt 2,054) resulting in a premature stop codon within the cod- ing region at nt 2,075, thus generating a plasmid capable of producing only a $\mathrm{C}$ terminal truncated $\mathrm{N}$ protein of $27 \mathrm{kDa}$. The pTSWVN+ plasmid was verified by sequence analysis to produce a full-length $\mathrm{N}$ protein. Constructs were initially tested in Nicotiana tabacum cv. Burley 21 to ensure their efficacy for TSWV resistance prior to their placement in chrysanthemum. All constructs were effective in yielding tobacco plants resistant to the parent isolate TSWV-D (19).

The plasmids were transferred into Agrobacterium tumefaciens strain EHA105 by a freeze-thaw procedure described by An et al. (2). Agrobacterium colonies containing the plasmids were selected and maintained on yeast extract peptone (YEP)

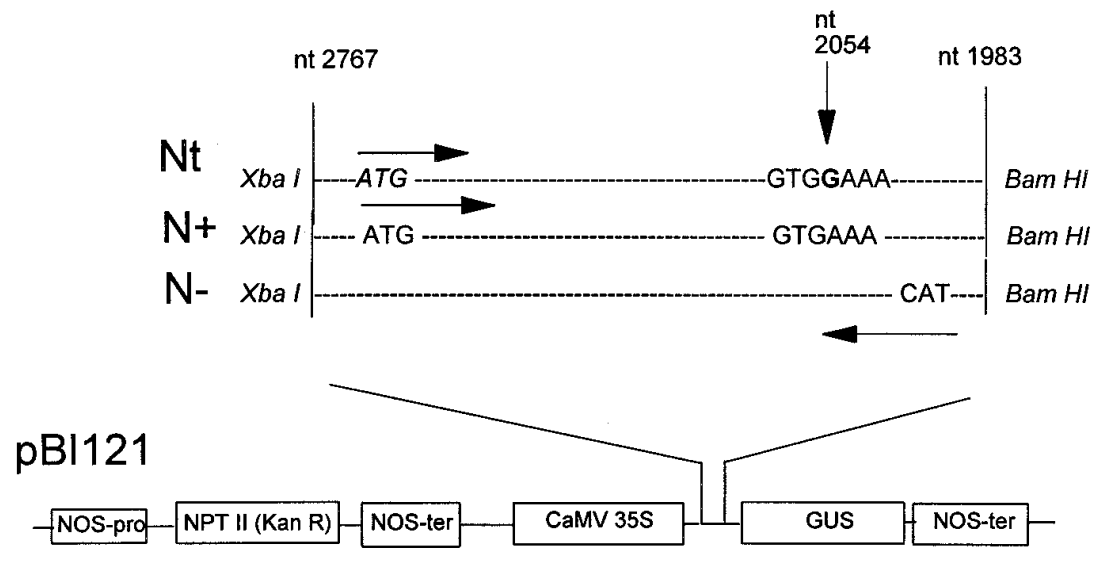

Fig. 1. Construction of vectors that express tomato spotted wilt virus (TSWV) $\mathrm{N}$ genes in plants. Steps involved in the preparation of these constructs are described in Materials and Methods. NOSpro, nopaline synthase promoter; NPTII, neomycin phosphotransferase II encoding kanamycin resistance; NOS-ter, nopaline synthase terminator; CaMV 35S, cauliflower mosaic virus 35S RNA promoter; GUS, $\beta$-glucuronidase. $\mathrm{Nt}, \mathrm{N}+$, and $\mathrm{N}$ - represent different versions of the tomato spotted wilt virus nucleocapsid protein gene. The $\mathrm{Nt} \mathrm{N}$ gene has an additional $\mathrm{G}$ at nucleotide position 2,054, resulting in a premature stop codon and the production of a $27-\mathrm{kDa}$ protein instead of a $29-\mathrm{kDa}$ protein. Horizontal arrows denote the orientation of the $\mathrm{N}$ genes. The different $\mathrm{N}$ gene versions were amplified by polymerase chain reaction (PCR) with the addition of $\mathrm{XbaI}$ and Bam HI sites at the termini to facilitate cloning into $\mathrm{pBI} 121$ following the CaMV $35 \mathrm{~S}$ promoter.

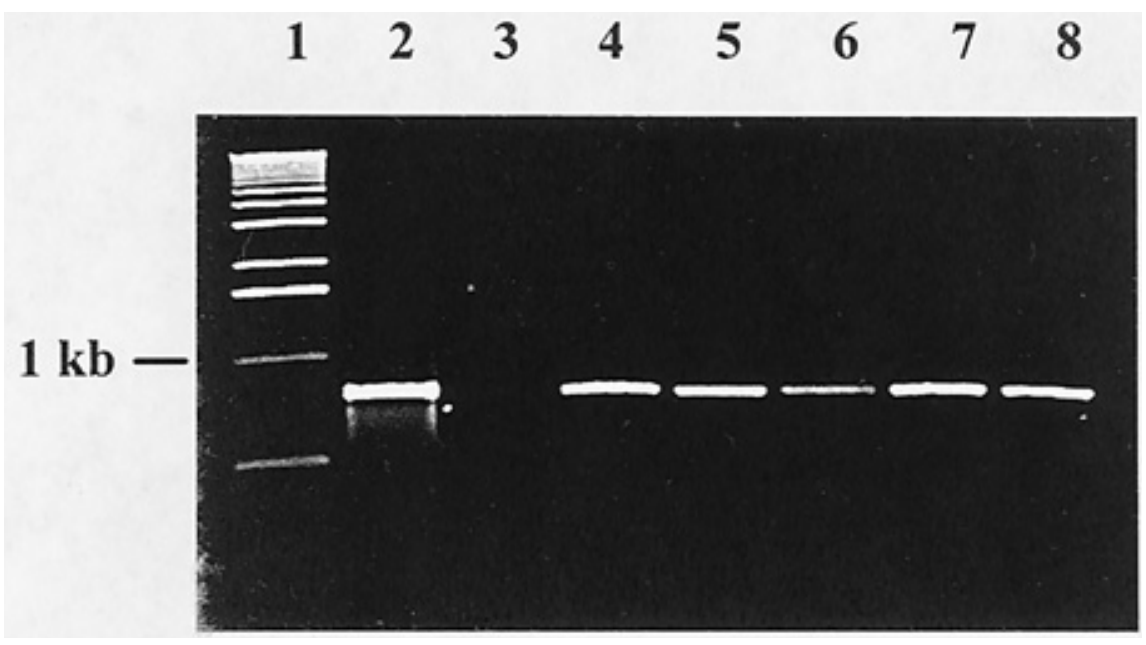

Fig. 2. Polymerase chain reaction (PCR) analysis of putative transgenic chrysanthemum cv. Polaris plants. Fragments were amplified with primers specific to the tomato spotted wilt virus (TSWV) N gene. Lane 1, 1-kb ladder DNA standard; lane 2, pTSWVN+ plasmid positive control; lane 3, nontransformed plant; lanes 4 to 8 , four independently transformed Polaris plants. The observed PCRgenerated products were of the expected size of about $780 \mathrm{bp}$. media (2) amended with kanamycin at 50 $\mu \mathrm{g} / \mathrm{ml}$.

Plant transformation and regeneration. Polaris leaf explants were transformed with Agrobacterium strain EHA105 containing pBI121, pTSWVN+, pTSWVNt, or pTSWVN- using the procedure of Sherman et al. (37). Leaf disks were treated with bacteria and placed initially on a regeneration medium (Mum 2,4D medium) (37) consisting of basal MS medium (30) with the addition of indoleacetic acid (IAA) at $2.0 \mathrm{mg} / \mathrm{liter}$, benzyladenine at $0.23 \mathrm{mg} / \mathrm{liter}$, and 2,4-diphenoxyacetic acid $(2,4-\mathrm{D})$ at $0.5 \mathrm{mg} / \mathrm{liter}$. After 5 days, co-cultivation was terminated and selection of transformed cells was initiated by transfer of explants to Mum 2,4-D medium containing carbenicillin at $500 \mathrm{mg} / \mathrm{liter}$ and paromomycin at 50 $\mathrm{mg} / \mathrm{liter}$. When callus proliferated, explants were moved to the same medium without 2,4-D and were maintained on this medium until developing shoot primordia were observed. Callus and shoot primordia were then transferred to a shoot elongation medium (Mum EL medium) consisting of MS medium with the addition of kinetin at 2.0 $\mathrm{mg} /$ liter, naphthalene-acetic acid (NAA) at $0.02 \mathrm{mg} / \mathrm{liter}$, and gibberellic acid at 10 $\mathrm{mg} /$ liter, again containing carbenicillin and paromomycin. After 4 to 6 weeks, elongated shoots were excised and transferred to rooting medium (25\% MS medium supplemented with NAA at $0.1 \mathrm{mg} / \mathrm{liter}$ and containing carbenicillin and paromomycin). Following rooting on selective medium, putative transformed plants were established in soil in the greenhouse.

PCR analysis of putative transformed plants. The presence of the $\mathrm{N}$ gene in plants that regenerated and rooted on selective media was confirmed by polymerase chain reaction (PCR) analysis. Genomic DNA was extracted from leaf tissue using the CTAB procedure of McGarvey and Kaper (29). Polysaccharides were removed from the samples by high salt precipitation (14). Genomic DNA $(0.5 \mu \mathrm{g})$ was PCR-amplified using primers specific for the TSWV N gene. PCR amplification was conducted in $100-\mu \mathrm{l}$ volumes with a denaturation step at $94^{\circ} \mathrm{C}$ for 1 min, an annealing step at $55^{\circ} \mathrm{C}$ for $1 \mathrm{~min}$, and an extension step at $72^{\circ} \mathrm{C}$ for $2 \mathrm{~min}$, for a total of 30 cycles.

Southern and northern analysis. Southern and Northern analysis were performed on selected resistant and susceptible original transformants. For Southern analysis, genomic DNA was isolated as described above and digested with $X b a \mathrm{I}$, which cuts the $\mathrm{N}$ gene constructs at a single site upstream of the $5^{\prime}$ end of the $\mathrm{N}$ gene coding sequence. Samples $(30 \mu \mathrm{g})$ were separated by electrophoresis and transferred to Magnagraph $0.45-\mu \mathrm{m}$ filters (Micron Separations, Westboro, MA). Genomic DNA containing $\mathrm{N}$ gene sequences were detected by hybridization 
with a ${ }^{32} \mathrm{P}$-labeled $\mathrm{N}$ gene fragment amplified from pTSWVN+.

For Northern analysis, total RNA was isolated using the RNA Isolator Kit (Genosys Biotechnologies, Woodlands, TX). Polyadenylated RNA was then isolated from these preparations using the Oligotex mRNA Mini Kit (Qiagen, Los Angeles, CA). Samples $(2 \mu \mathrm{g})$ of polyadenylated RNA were resolved by formaldehyde gel electrophoresis, transferred, and probed as described for Southern analysis.

ELISA and Western analysis. For detection of $\mathrm{N}$ protein production by Western analysis, newly expanded leaves were ground in $10 \mathrm{mM}$ Tris- $\mathrm{HCl}$ (pH 7.8) buffer (1:25 wt/vol). Following centrifugation for 2 min at $100 \times g$, supernatants were combined with an equal volume of $2 \times$ dissociation buffer (21). Electrophoresis and electrotransfer of protein samples $(50 \mu \mathrm{g})$ was performed as described by Gray et al. (17). Antiserum made to purified TSWV-D virions (22) and an alkaline phosphatase conjugate-nitro blue tetrazolium/5-bromo4-chloro-3-indolylphosphate reporter system (25) were employed for $\mathrm{N}$ protein detection.

Enzyme-linked immunosorbent assay (ELISA) was performed on uninoculated transformed plants for detection of $\mathrm{N}$ protein expression. ELISA showed no detectable levels of plant-produced $\mathrm{N}$ protein in any of the transformants; thus ELISA was used to assay for virus titers in inoculated plants. Tissue was harvested from the upper portions of inoculated transformed plants in order to determine if symptomless infections were occurring. The doubleantibody sandwich (DAS-ELISA) protocol of Clark and Adams (7) was utilized along with the antiserum used for Western analysis. In the inoculation tests, plants with tissue samples giving $A_{405}$ readings less than 0.05 were considered noninfected, a value chosen based on a study of ELISA values of healthy plants of 29 cultivars of chrysanthemum over a 7-month period (28).

Virus inoculation of transgenic chrysanthemum plants. TSWV-D, the isolate used for cloning the $\mathrm{N}$ gene for plant transformation, was found to be weakly virulent on chrysanthemum. Therefore, a highly virulent strain of TSWV (TSWV-GB) isolated from systemically infected chrysanthemum (cv. Golden Bounty) plants obtained from a greenhouse in North Carolina was used for resistance screening. TSWV-GB was maintained by mechanical transfer into Datura stramonium L. For inoculation of D. stramonium, infected tissue was homogenized (1:20 dilution) in inoculation buffer $(0.1 \mathrm{M}$ Tris- $\mathrm{HCl}, 10$ $\mathrm{mM} \mathrm{Na} \mathrm{SO}_{3}$, and $10 \mathrm{mM}$ cysteine) and applied with cotton-tipped applicators to the young uppermost leaves previously dusted with Carborundum, followed by rinsing with water.

Initial tests for resistance were performed via thrips inoculation on single cuttings from each transformed plant. Analysis of tobacco plants transformed with these constructs demonstrated that only 4 to $20 \%$ of transformed plants (depending on construct and cultivar) have agronomically acceptable levels of resistance to TSWV (19); thus a rapid screen was needed to identify the expected large number of TSWV-susceptible lines. Cuttings were made from 152 pTSWVN+, 37 pTSWVNt, and 47 pTSWVN- original transformants and from nontransformed and pBI121-transformed plants as controls. A thriving thrips colony was established in an enclosed greenhouse chamber on TSWV-GB-infected chrysanthemum and D. stramonium plants. Test plants were placed in a random arrangement within the chamber, and viruliferous thrips were allowed to continuously feed on the plants. Symptom data and ELISA values were recorded after 10 weeks. Only plants devoid of symptoms of systemic infection and without detectable levels of virus by ELISA were scored as resistant.

Transformed plants that were scored as resistant in the initial thrips inoculation test were then tested by mechanical inoculation. Ten cuttings from the resistant chrysanthemum transformants and from nontransformed, pBI121-transformed, and several known TSWV-susceptible transformed lines were used. Cuttings were preconditioned by wrapping them in moist paper towels and placing them in the dark at $14^{\circ} \mathrm{C}$ overnight. The three lowest leaves of each cutting were inoculated. The inoculated cuttings were rewrapped in moist paper towels and given another dark, $14^{\circ} \mathrm{C}$ exposure overnight. Cuttings were then planted in pots in the greenhouse and allowed to become established. Mechanical inoculations were repeated at 2 weeks and 4 weeks after planting. No preconditioning of plants was performed at these times, and inoculation was limited only to those leaves inoculated initially. Inoculated plants were monitored over a 3-month period for the development of symptoms and were also assayed by ELISA.

\section{RESULTS}

Transformation of Polaris plants. A total of 236 Polaris regenerants transformed with the $\mathrm{N}$ gene constructs survived continuous exposure to the selection agent, paromomycin, were established in soil, and were maintained in the greenhouse. PCR analysis of 72 randomly chosen Polaris plants that survived selection indicated that $96 \%$ of regenerates contained the TSWV N gene sequences (Fig. 2).

Inoculation tests. In the initial screen, a single rooted cutting from each transformed plant was challenged continuously for 10 weeks by viruliferous thrips vectoring TSWV-GB. The time required for symptom development was variable but averaged about 4 weeks for initial symptom appearance. The first detectable symptoms were chlorotic spots representing initial TSWV-infection sites. These were present on leaves of all plants tested, indicating that all test plants were successfully inoculated by thrips. More severe and extensive leaf chlorosis and necrosis, petiole necrosis, apical bud death, flower head

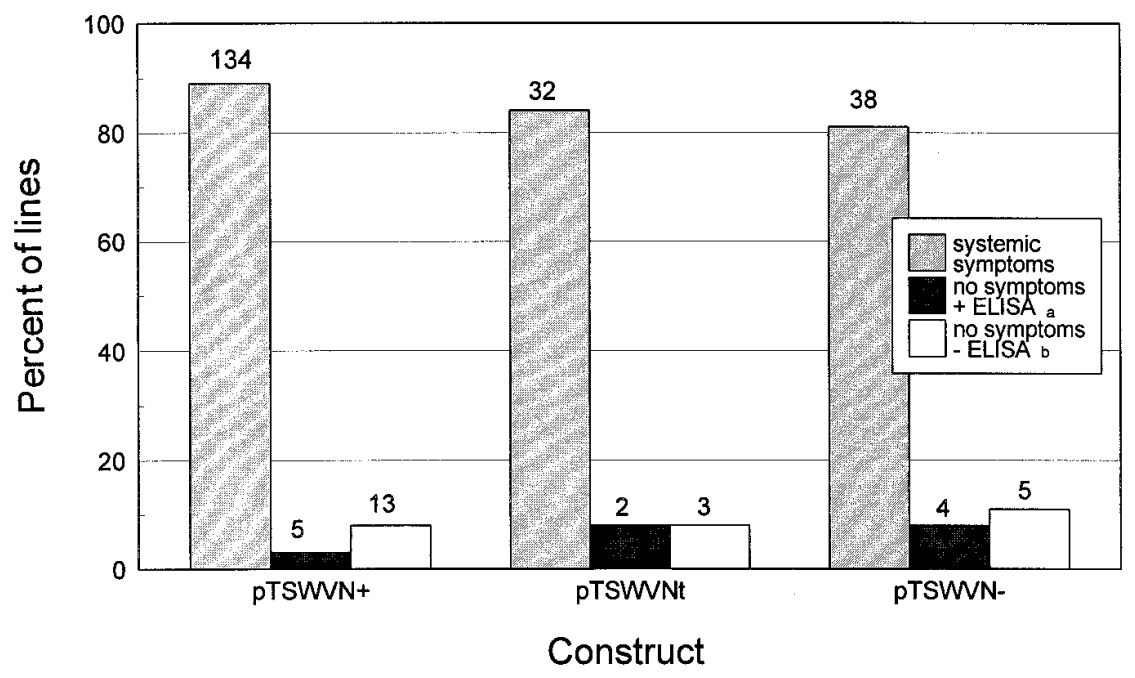

Fig. 3. Reactions of single cuttings made from tomato spotted wilt virus (TSWV) N gene-transformed chrysanthemum cv. Polaris plants to inoculation by thrips vectoring TSWV-GB after 10 weeks. Bars indicate the percentage of plants transformed with the three TSWV N gene constructs that: (i) expressed systemic symptoms, (ii) had no systemic symptoms but positive enzyme-linked immunosorbent assay (ELISA) values, or (iii) had no systemic symptoms and negative ELISA values. The numbers above the bars represent the actual numbers of plants with the different reactions. ELISA > 0.05 indicated systemic movement of TSWV and the plant was rated as susceptible. ELISA $<0.05$ indicated the lack of virus movement into the upper regions of the transgenic plant. ELISA samples were prepared from tissue taken from the uppermost leaves of inoculated plants. ELISA analysis of uninoculated $\mathrm{N}$ gene-transformed plants indicated no detectable levels of $\mathrm{N}$ protein. Plants with no systemic symptoms and ELISA $<0.05$ were scored resistant. 
crooking, and large stem cankers were evident in the majority of plants by 8 weeks after inoculation. Final symptom data was collected at 10 weeks, when $100 \%$ of the nontransformed and pBI121 vector-transformed controls showed extensive symptom development (Fig. 3). While $100 \%$ of control plants showed systemic symptoms, several plants transformed with each construct had no visible symptoms of systemic infection, although the initial TSWV-infection sites were evident on the older leaves of these plants.

ELISA was performed on tissue from the upper regions of nonsymptomatic plants to detect latent infections. Plants with no symptoms and ELISA values $<0.05$ were rated as resistant. From this initial screen, a total of 13 pTSWVN+, 3 pTSWVNt, and 5 pTSWVN- original transformants were scored as resistant (Fig. $3)$.

The resistance identified in the initial test was verified by repeated thrips inoculation of three cuttings derived from four transformants initially scored as resistant (Table 1). For lines $\mathrm{N}+33$ and $\mathrm{N}+42$, no cuttings exhibited symptoms of systemic TSWV infection. These lines also had ELISA values $<0.05$, indicating the absence of latent infections. Some or all of the cuttings from two other lines $(\mathrm{N}+31$ and $\mathrm{N}+61$ ) that were scored as resistant in the initial test with single cuttings, however, did develop some symptoms of systemic TSWV infection and also had positive ELISA values $(>0.05)$ in nonsymptomatic tissue at the top of the plants, confirming the presence of TSWV.

Following the initial thrips screen, multiple cuttings from original transformants scored as resistant were tested in a more rigorous inoculation trial. Because mechanical inoculation of chrysanthemum with TSWV can be difficult, three rounds of inoculation were performed. As with the thrips inoculation trials, initial infection sites (chlorotic and necrotic lesions) were observed on the inoculated leaves of all plants at 4 weeks after the first inoculation date, with systemic symptoms becoming evident in susceptible plants at 8 weeks.

Table 2 shows the final reactions (at 16 weeks) of cuttings taken from 19 transformants identified as resistant, 11 transformants identified as susceptible, and two transformants that gave variable ratings in thrips inoculation tests. With mechanical inoculation, $100 \%$ of nontransformed and vector-transformed control plants became systemically infected. Cuttings from transgenic plants identified as susceptible in the thrips screen also showed a high incidence of systemic infection in this test, as did lines that gave variable reactions in thrips tests.

Of the transformed plants that gave resistant ratings in the thrips tests, three were identified (N-1a, N-13b, and Nt19) that exhibited a total lack of systemic TSWV symptoms and no detectable levels of virus accumulation in all 10 cuttings. Other plants $(\mathrm{N}+98, \mathrm{~N}+120, \mathrm{Nt11}, \mathrm{Nt} 45, \mathrm{~N}-7 \mathrm{x}$, and $\mathrm{N}-8 \mathrm{x}$ ) were scored as moderately resistant, as their cuttings exhibited a lower incidence or lack of the destructive necrotic symptoms of the disease, stem cankers and apical bud death (Table 2), and also showed a delay in development of all symptoms. At 12 weeks after the first inoculation, only 20 to $45 \%$ of cuttings derived from these six plants exhibited symptoms of systemic TSWV infection. By contrast, more than $70 \%$ of nontransformed and vector-transformed controls exhibited systemic TSWV infection at that time.

Molecular analysis of TSWV-resistant and -susceptible plants. Northern analysis was performed on original transformants whose cuttings were evaluated in the inoculation tests. Transgene transcript levels were very low in all transgenic chrysanthemum plants tested, being undetectable when $30 \mu \mathrm{g}$ of total RNA was examined by Northern blot analysis (results not shown) but detectable with polyadenylated RNA (Fig. 4). Analysis of three resistant and three susceptible transformants demonstrated that all three resistant transformants
(Nt19, N-1a, and N-13b) had detectable levels of N gene mRNA (Fig. 4). Two of the susceptible transformants $(\mathrm{N}-2 \mathrm{e}$ and Nt4) had no detectable mRNA; however, a third susceptible transformant $(\mathrm{N}-2 \mathrm{~d})$ had a greater level of $\mathrm{N}$ gene mRNA than did two of the resistant transformants.

To determine if $\mathrm{N}$ protein was involved in conferring resistance, protein samples from the $\mathrm{N}+$ and $\mathrm{Nt}$ original transformants whose cuttings were tested in the mechanical inoculation test were assayed by both Western analysis and ELISA. No bands were found by Western analysis, and ELISA values averaged 0.021 (range 0.008 to 0.039 ) compared with 0.023 for vectortransformed plants. Thus, all transformed plants showed no detectable levels of plant-produced $\mathrm{N}$ protein.

Southern analysis of XbaI-digested genomic DNA confirmed the stable integration of the $\mathrm{N}$ gene (Fig. 5). Resistant transformants had at least three insertion sites within their genomes. Some TSWVsusceptible transformants had a similar number of insertion sites, while others only had a single integration site.

\section{DISCUSSION}

Transformation of the highly TSWVsusceptible chrysanthemum cultivar Polaris with the $\mathrm{N}$ gene of TSWV resulted in the generation of nine transformed plant lines with moderate to high levels of resistance to TSWV infection. Resistance was expressed when plants were challenged with the virus by either thrips or mechanical inoculation. Expression of resistance ranged from lines that were completely resistant to systemic spread of the virus to ones that displayed a delay in the development of systemic symptoms and a lack or reduced incidence of destructive canker and bud die-back symptoms. This study is the first report of chrysanthemum plants with resistance to this virus and the first report of genetic engineering of chrysanthemum for resistance to any disease. Although both Urban et al. (40) and Yepes et al. (43) reported on the transformation and

Table 1. Reactions of multiple cuttings made from tomato spotted wilt virus (TSWV) N gene-transformed chrysanthemum cv. Polaris plants to inoculation by thrips vectoring TSWV-GB after 10 weeks

\begin{tabular}{|c|c|c|c|c|c|c|c|c|}
\hline \multirow[b]{2}{*}{ Line } & \multirow{2}{*}{$\begin{array}{l}\text { Initiala }^{\mathbf{a}} \\
\text { rating }^{2}\end{array}$} & \multicolumn{5}{|c|}{ Symptom expression $^{b}$} & \multirow[b]{2}{*}{+ ELISA $^{\mathrm{c}}$} & \multirow[b]{2}{*}{ Rating $^{\mathrm{d}}$} \\
\hline & & $\mathbf{C}$ & $\mathbf{L N}$ & PN & SC & $\overline{\text { ABD }}$ & & \\
\hline $\mathrm{N}+4$ & $\mathrm{~S}$ & 3 & 3 & 1 & 3 & 1 & 1 & $S$ \\
\hline $\mathrm{N}+7$ & S & 3 & 3 & 3 & 1 & 1 & 3 & S \\
\hline $\mathrm{N}+31$ & $\mathrm{R}$ & 3 & 2 & 1 & 0 & 0 & 3 & $\mathrm{~S}$ \\
\hline $\mathrm{N}+33$ & $\mathrm{R}$ & 0 & 0 & 0 & 0 & 0 & 0 & $\mathrm{R}$ \\
\hline $\mathrm{N}+42$ & $\mathrm{R}$ & 0 & 0 & 0 & 0 & 0 & 0 & $\mathrm{R}$ \\
\hline $\mathrm{N}+61$ & $\mathrm{R}$ & 2 & 2 & 2 & 1 & 0 & 2 & $\mathrm{~S}$ \\
\hline pBI121 & $\mathrm{S}$ & 2 & 2 & 1 & 2 & 1 & 2 & $\mathrm{~S}$ \\
\hline Nontransformed & $\mathrm{S}$ & 3 & 3 & 1 & 2 & 2 & 3 & $\mathrm{~S}$ \\
\hline
\end{tabular}

${ }^{a}$ Rating of initial transformant following initial thrips inoculation experiment. $\mathrm{S}=$ susceptible; $\mathrm{R}=$ resistant (no symptoms and enzyme-linked immunosorbent assay [ELISA] $<0.05)$.

${ }^{b}$ Data on symptom expression were collected after 10 weeks of thrips challenge. The number of plants of a total of three per line tested exhibiting systemic symptoms of chlorosis (C), leaf necrosis (LN), petiole necrosis (PN), stem canker (SC), and apical bud death (ABD) is indicated.

${ }^{\mathrm{c}}$ Nonsymptomatic leaves from the upper portion of the plants were assayed by ELISA to detect systemic spread of the virus. Tissue samples giving $A_{405}>$ 0.05 were considered positive for the presence of the virus.

${ }^{\mathrm{d}}$ Final rating of susceptible (S) or resistant (R). Only lines whose cuttings uniformly lacked symptoms and had ELISA $<0.05$ were considered resistant. 
integration of the TSWV N gene into chrysanthemum, neither report documented the recovery of resistant plants.

As with most studies on $\mathrm{N}$ gene-mediated protection against TSWV, the protection observed in the resistant chrysanthemum lines was manifested as a prevention of systemic infection by the virus rather than as a resistance to initial infection. TSWV infection sites were observed on the inoculated leaves of resistant plants in the mechanical inoculation study and were also present on the older leaves of plants inoculated by thrips. Similar results have been obtained in tobacco $(31,36,41)$ and tomato $(20,39)$ transformed with the TSWV N gene, where resistance was expressed as reduction in the development of systemic symptoms, ranging from a delay in systemic symptom expression to reduced severity of systemic symptoms to a complete lack of systemic symptoms. We observed all of these reactions in our lines. Systemic infection in the resistant lines was either prevented, as evidenced by the lack of symptoms and detectable levels of virus in the upper portions of plants, or delayed and of reduced severity. By contrast, in lettuce, Pang et al. (32) reported that transgenic plants expressing low levels of $\mathrm{N}$ protein showed a complete lack of both local and systemic symptoms upon challenge with the virus.

In our study, approximately $10 \%$ (21 of 204) of the transformants demonstrated resistance after the initial thrips inoculation tests. The mechanical inoculation test reduced the number of lines categorized as resistant or moderately resistant to those derived from nine transformed plants (approximately 4\%). The difference in the proportions of resistant plants upon thrips versus mechanical inoculation could be explained by the sporadic nature of thrips movement and feeding patterns, accounting for TSWV-susceptible plants escaping identification, but the consistent identification of localized lesions on challenged plants suggests otherwise. A more likely explanation is inoculum dose, which could account for both the variability in symptom expression in the different thrips tests as well as between the thrips and mechanical inoculation test. The mechanical inoculation test was a very severe test. As mechanical inoculation of chrysanthemum can be difficult (28), plants were inoculated a total of three times during a 2-month period. We also delayed rating the plants until 16 weeks (versus 10 weeks for the thrips inoculation tests). The severity of this test and the ability of lines to express resistance in the thrips test, however, suggests that the moderately resistant Polaris lines that exhibited symptom attenuation and delay may be adequate for

Table 2. Systemic symptoms and virus accumulation in tomato spotted wilt virus (TSWV) N gene-transformed chrysanthemum cv. Polaris plants following mechanical inoculation with TSWV-GBa

\begin{tabular}{|c|c|c|c|c|c|c|c|c|c|}
\hline \multirow{2}{*}{$\begin{array}{l}\text { Thrips } \\
\text { rating }\end{array}$} & \multirow[b]{2}{*}{ Line } & \multirow[b]{2}{*}{ No. ${ }^{c}$ tested } & \multicolumn{5}{|c|}{ Symptom expression $^{\mathrm{d}}$} & \multirow[b]{2}{*}{+ ELISA $^{\mathrm{e}}$} & \multirow{2}{*}{$\begin{array}{c}\text { Mechanical } \\
\text { rating }\end{array}$} \\
\hline & & & $\mathbf{C}$ & $\mathbf{L N}$ & PN & SC & $\overline{\text { ABD }}$ & & \\
\hline \multirow[t]{19}{*}{ Resistant } & $\mathrm{N}+33$ & 10 & 10 & 10 & 9 & 4 & 4 & 9 & $S$ \\
\hline & $\mathrm{N}+42$ & 10 & 10 & 9 & 7 & 4 & 6 & 8 & $S$ \\
\hline & $\mathrm{N}+56$ & 10 & 10 & 9 & 7 & 3 & 6 & 10 & $\mathrm{~S}$ \\
\hline & $\mathrm{N}+62$ & 10 & 0 & 10 & 5 & 0 & 7 & 9 & $\mathrm{~S}$ \\
\hline & $\mathrm{N}+65$ & 10 & 10 & 9 & 4 & 0 & 6 & 9 & $\mathrm{~S}$ \\
\hline & $\mathrm{N}+68$ & 10 & 10 & 10 & 10 & 3 & 6 & 9 & $\mathrm{~S}$ \\
\hline & $\mathrm{N}+88$ & 8 & 7 & 6 & 4 & 0 & 2 & 6 & $\mathrm{~S}$ \\
\hline & $\mathrm{N}+98$ & 10 & 0 & 9 & 5 & 1 & 0 & 5 & MR \\
\hline & $\mathrm{N}+102$ & 10 & 10 & 10 & 1 & 0 & 3 & 10 & $\mathrm{~S}$ \\
\hline & $\mathrm{N}+120$ & 10 & 10 & 10 & 5 & 0 & 2 & 7 & MR \\
\hline & $\mathrm{N}+162$ & 10 & 8 & 6 & 5 & 1 & 3 & 10 & $\mathrm{~S}$ \\
\hline & Nt11 & 10 & 10 & 9 & 9 & 0 & 0 & 1 & MR \\
\hline & Nt19 & 10 & 0 & 0 & 0 & 0 & 0 & 0 & $\mathrm{R}$ \\
\hline & $\mathrm{Nt} 45$ & 10 & 9 & 8 & 6 & 0 & 1 & 6 & MR \\
\hline & $\mathrm{N}-1 \mathrm{a}$ & 10 & 0 & 0 & 0 & 0 & 0 & 0 & $\mathrm{R}$ \\
\hline & $\mathrm{N}-13 \mathrm{~b}$ & 10 & 0 & 0 & 0 & 0 & 0 & 0 & $\mathrm{R}$ \\
\hline & $N-7 x$ & 9 & 9 & 9 & 5 & 0 & 0 & 8 & MR \\
\hline & $N-8 x$ & 9 & 9 & 7 & 5 & 0 & 1 & 9 & MR \\
\hline & $\mathrm{N}-12 \mathrm{x}$ & 10 & 10 & 10 & 3 & 1 & 2 & 10 & $\mathrm{~S}$ \\
\hline \multirow[t]{2}{*}{ Variable } & $\mathrm{N}+31$ & 10 & 9 & 9 & 8 & 1 & 5 & 6 & S \\
\hline & $\mathrm{N}+61$ & 10 & 10 & 7 & 6 & 2 & 7 & 10 & $\mathrm{~S}$ \\
\hline \multirow[t]{11}{*}{ Susceptible } & $\mathrm{N}+4$ & 10 & 10 & 6 & 7 & 1 & 9 & 10 & $\mathrm{~S}$ \\
\hline & $\mathrm{N}+7$ & 10 & 10 & 9 & 8 & 3 & 4 & 7 & $S$ \\
\hline & $\mathrm{N}+84$ & 10 & 10 & 4 & 2 & 3 & 4 & 8 & S \\
\hline & $\mathrm{N}+87$ & 10 & 10 & 9 & 9 & 1 & 5 & 10 & S \\
\hline & $\mathrm{N}+119$ & 8 & 8 & 8 & 6 & 2 & 2 & 8 & $\mathrm{~S}$ \\
\hline & $\mathrm{Nt} 4$ & 10 & 10 & 7 & 7 & 1 & 2 & 3 & $\mathrm{~S}$ \\
\hline & $\mathrm{Nt} 23$ & 10 & 10 & 9 & 8 & 3 & 1 & 2 & $\mathrm{~S}$ \\
\hline & Nt31 & 10 & 9 & 8 & 3 & 1 & 2 & 3 & $\mathrm{~S}$ \\
\hline & $\mathrm{N}-1 \mathrm{c}$ & 10 & 9 & 8 & 4 & 0 & 3 & 6 & S \\
\hline & $N-2 d$ & 10 & 9 & 10 & 6 & 1 & 8 & 9 & $\mathrm{~S}$ \\
\hline & $\mathrm{N}-2 \mathrm{e}$ & 10 & 10 & 9 & 5 & 2 & 5 & 9 & $\mathrm{~S}$ \\
\hline \multirow[t]{2}{*}{ Controls } & pBI121 & 10 & 10 & 10 & 10 & 2 & 6 & 9 & $\mathrm{~S}$ \\
\hline & Nontransformed & 10 & 9 & 9 & 9 & 6 & 9 & 10 & $\mathrm{~S}$ \\
\hline
\end{tabular}

${ }^{a}$ Cuttings of selected lines were mechanically inoculated with a 1:20 (wt/vol) dilution of leaf crude extracts of TSWV-GB-infected Datura stramonium. Inoculation was performed three times: prior to planting, 2 weeks after planting, and 4 weeks after planting. The same leaves were inoculated each time.

${ }^{b}$ Rating following thrips inoculation. Lines ranked as variable had different ratings in two thrips tests. Lines $\mathrm{N}+33$ and $\mathrm{N}+42$ gave resistant reactions in two thrips tests, and lines $\mathrm{N}+4$ and $\mathrm{N}+7$ were susceptible in two tests. All other thrips ratings were derived from a single test.

${ }^{\mathrm{c}}$ Number of cuttings tested per line.

${ }^{\mathrm{d}}$ Data on systemic symptom expression were collected 16 weeks after first inoculation. The number of plants exhibiting chlorosis (C), leaf necrosis (LN), petiole necrosis (PN), stem canker (SC), and apical bud death (ABD) is indicated.

${ }^{\text {e }}$ Enzyme-linked immunosorbent assays (ELISA) were run on young nonsymptomatic tissue 16 weeks after planting. Tissue samples giving $A_{405}>0.05$ were considered positive for the presence of the virus.

${ }^{\mathrm{f}}$ Reaction to mechanical inoculation, susceptible (S), moderately resistant (MR), or resistant (R). Only lines whose cuttings uniformly lacked symptoms and had ELISA $<0.05$ were considered fully resistant. Moderately resistant lines had $<20 \%$ of plants exhibiting severe symptoms and showed a delay in symptom expression. 
TSWV control in commercial chrysanthemum production.

It is difficult to make exact comparisons with previous studies on transgenic tomato and tobacco, as different studies utilized different criteria for evaluating a transgenic line as resistant. However, the proportion of resistant plants recovered in our studies

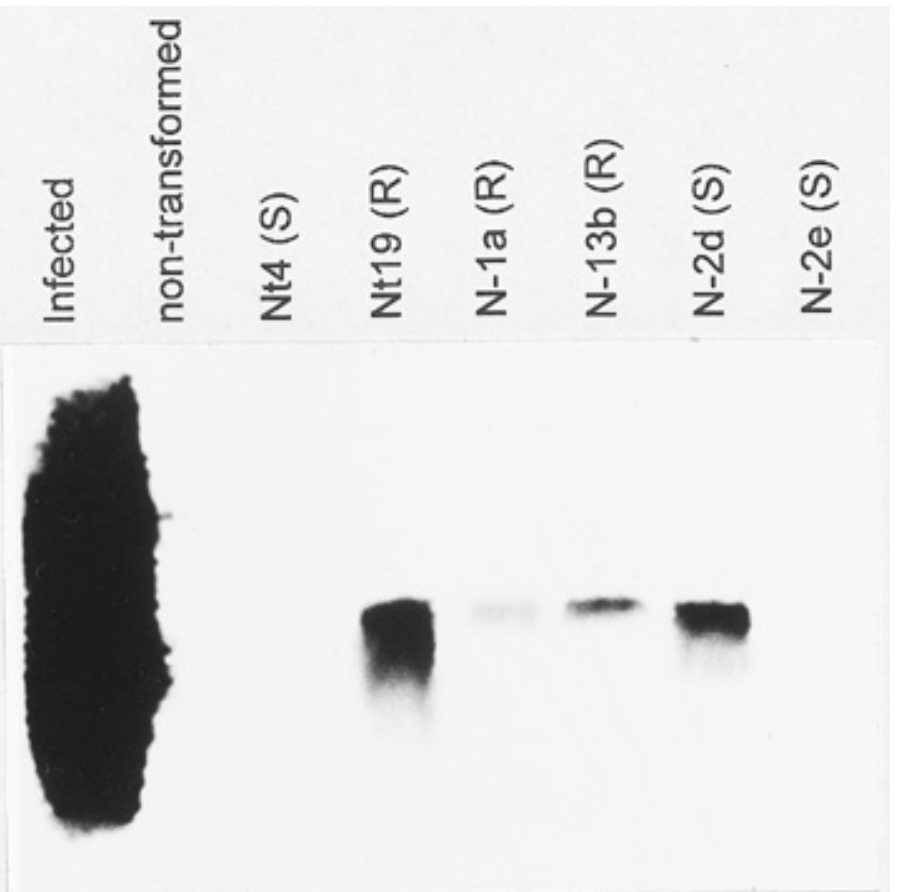

Fig. 4. Northern blot hybridization analysis of chrysanthemum cv. Polaris transformants. Polyadenylated RNA ( $2 \mu \mathrm{g})$ was isolated from the original transformants and was separated by formaldehyde gel electrophoresis. Hybridization was with a ${ }^{32} \mathrm{P}$-labeled probe specific for the coding region of the nucleocapsid gene of tomato spotted wilt virus (TSWV). Lane 1, RNA $(0.5 \mu \mathrm{g})$ isolated from TSWV-GB-infected plant; lane 2, RNA from nontransformed Polaris plant; lanes 3 to 8 , polyadenylated RNA from pTSWVNt and pTSWVN- transformed Polaris plants. The plant lines are designated as susceptible (S) or resistant (R).

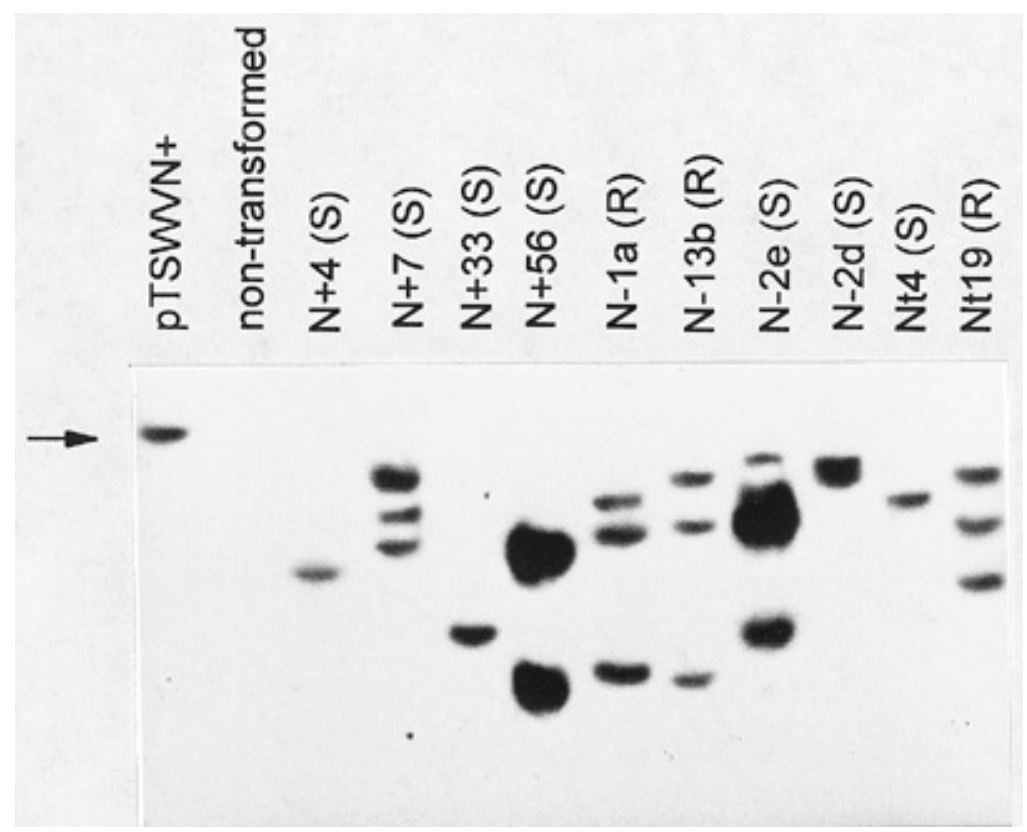

Fig. 5. Southern blot hybridization analysis of chrysanthemum cv. Polaris transformants. Total genomic DNA $(30 \mu \mathrm{g})$ was isolated from the transformants and digested with XbaI. Digestion of the

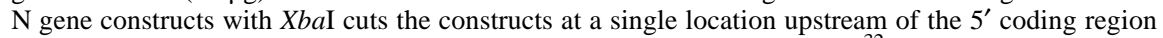
of the tomato spotted wilt virus (TSWV) $\mathrm{N}$ gene. Hybridization was with a ${ }^{32} \mathrm{P}$-labeled probe specific for the coding region of the nucleocapsid gene of TSWV. Lane 1, purified pTSWVN+ digested with $\mathrm{XbaI}$ to produce a 13.8-kb plasmid band (arrow); lane 2, DNA from nontransformed Polaris plant; lanes 3 to 12, DNA from pTSWVN+, pTSWVN-, and pTSWVNt transformed Polaris plants. The plant lines are designated as susceptible (S) or resistant (R).

appears to be less than those reported in studies of $\mathrm{N}$ gene-transformed tobacco and tomato. There are several factors that may explain this difference. First, we chose to define as resistant only those plants that had a uniform lack (or attenuation and delay) of systemic symptoms in all cuttings challenged. Other studies have defined a transformant as resistant if a proportion of the transgenic $R_{1}$ or $R_{2}$ progeny did not develop systemic symptoms. For example, lines with as few as 20 to $50 \%$ of transgenic progeny lacking systemic symptoms upon challenge have been defined as resistant, although lines with $100 \%$ resistant progeny could also be isolated $(11,20,36,39)$. Because we are working with a vegetatively propagated crop (and thus cuttings should be genetically uniform), and because of the large variability in normal symptom expression in susceptible chrysanthemums and our interest in producing plants with utility in disease management, we adopted this more strict definition of resistance. Other factors beyond stringent criteria probably also affected the frequency of resistance. We utilized a heterologous virus isolate for our screening. Although we confirmed the ability of our constructs to impart resistance to this isolate, it has been shown that lower levels of resistance are achieved when transformed plants are inoculated with virus isolates related to, but distinct from, the isolate originally used to obtain the $\mathrm{N}$ gene (41). Also, we have found that the level of transgene (GUS) expression is approximately 10 -fold lower in chrysanthemum than in tobacco transformed with the same constructs $(8,37,40)$; thus reduced levels of resistance may be due to a lower level of $\mathrm{N}$ gene expression. We were unable to detect $\mathrm{N}$ protein accumulation in our transgenic chrysanthemum plants; whereas $\mathrm{N}$ protein accumulation was detected in studies of tobacco, tomato, and lettuce $(20,31,32,36,39,41)$.

Although our study is the only one to date that has analyzed TSWV N gene-mediated resistance in a vegetatively propagated crop, some comparisons can be drawn with the results of Vaira et al. (41), who evaluated clonally propagated primary transformants of Nicotiana benthamiana and found that the expression of resistance varied even in clonally propagated material. They concluded that the expression of resistance was highly variable and was significantly impacted by differences in plant age, growth conditions, and inoculum concentration, resulting in differential responses in different tests ranging from expression of partial protection to complete susceptibility. We also observed environmental effects on resistance. In one test, when inoculated plants of the three resistant lines were exposed to a period of cooler night temperatures $\left(20^{\circ} \mathrm{C}\right.$ versus $25^{\circ} \mathrm{C}$ ) for 10 days, small ( $<5 \mathrm{~mm}$ diameter) lesions developed in the major vein of 
some leaves. These lesions were observed for 1 month, and while the virus was detected by ELISA, the lesions did not expand and no further symptoms developed. Environmental conditions are known to affect the expression of transgenes in plants and have proven to be a concern for genetically engineered resistance $(5,38)$. Pang et al. (32) found that transgene expression levels and TSWV resistance in lettuce were affected by the developmental stage of the plants and the time of the year when inoculations were performed. It is possible that environmental changes could affect resistance in two ways: by changing transgene expression levels and also by promoting virus replication. Susceptibility of chrysanthemum to TSWV is known to increase at cooler temperatures (28).

Past studies have proposed that virus resistance in transgenic plants is due to two mechanistically different activities. TSWV $\mathrm{N}$ gene-mediated protection against other tospoviruses has been correlated with high levels of $\mathrm{N}$ protein accumulation by the transgenic plant $(31,33,41)$. The protein produced by the plant is believed to act as a dysfunctional protein that interferes with the replication of the nonhomologous virus (33). By contrast, TSWV N gene-mediated protection against different isolates of TSWV has shown either no correlation between protein levels and expression of resistance $(11,20)$ or significantly better resistance in lines with low levels of protein expression $(31-33,41)$. In TSWV $\mathrm{N}$ gene-transformed lettuce, for example, Pang et al. (32) reported an absolute correlation between $\mathrm{N}$ gene expression and the phenotype of resistance. All low-expressing plants were completely protected against both local and systemic infection; whereas all plants expressing moderate to high levels of $\mathrm{N}$ protein had less resistance, expressed as fewer local lesions and delayed or lack of systemic symptoms. No N protein accumulation was detected in any of the transformed Polaris plants tested in our study. Yepes et al. (43) and Urban et al. (40) transformed other cultivars of chrysanthemum with TSWV N gene sequences and were also unable to detect $\mathrm{N}$ protein production. This fact provides further evidence that gene expression levels in chrysanthemum are lower than in other plants, and also suggests that RNA-mediated protection against TSWV may be operating in the resistant Polaris plants.

RNA-mediated protection against TSWV has been shown to function against strains of the virus sharing significant levels of homology between their $\mathrm{N}$ gene and the transgene $(33,41)$. A high rate of transgene transcription is thought to result in the activation of an RNA degradation mechanism resulting in low levels of accumulation of transgene message in the cytoplasm. As a result, the RNA of the challenging virus is also targeted for degradation, and the replication of the virus is suppressed $(6,26)$. In our study, however, comparisons of the transgene mRNA levels between the resistant Polaris transformants and an equal number of susceptible transformants revealed no correlation between mRNA levels and resistance. Gene dosage and copy number have also been shown to have an effect on this co-suppression phenomenon $(16,32)$, as the greater the number of transcriptionally active genes inserted in the plant's genome, the better the chances that the threshold level of message will be reached that is necessary for the activation of specific RNA degradation. Comparison of the number of transgene insertion sites among selected TSWV-resistant and -susceptible Polaris plants, however, showed no clear pattern.

The primary objective of this work was to develop transgenic chrysanthemum plants that have commercially acceptable levels of resistance to TSWV. We have developed nine lines of plants with high to moderate levels of resistance to high inoculum pressure from the virus transmitted either mechanically or by thrips, thus expanding the use of $\mathrm{N}$ gene-mediated TSWV resistance from tobacco and two vegetable crops (lettuce and tomato) to a major ornamental crop. Coupled with conventional control practices where thrips populations are already managed in order to prevent feeding damage on flowers and foliage, these lines can provide commercial growers with an additional tool for avoiding the devastating losses associated with TSWV, since previous control measures have not been highly effective. The TSWV-resistant lines may also be used in breeding programs to introduce resistance into new cultivars of chrysanthemum, a crop where no TSWV resistance existed before. Currently, the TSWV-resistant Polaris lines are being evaluated in an industrial setting to determine their utility for practical crop improvement.

\section{ACKNOWLEDGMENTS}

We thank Sue Geske, Jan Speck, and Jorge Abad for construction of the TSWV N gene vectors. We also thank Stan Gelvin for the gift of Agrobacterium tumefaciens strain EHA105. This work was funded by grants from the American Floral Endowment and the North Carolina Biotechnology Center.

\section{LITERATURE CITED}

1. Allen, W. R. and Broadbent, A. B. 1986. Transmission of tomato spotted wilt virus in Ontario greenhouses by Frankliniella occidentalis. Can. J. Plant Pathol. 8:33-38.

2. An, G., Ebert, P. R., Mitra, A., and Ha, S. B. 1988. Binary vectors. Pages A3:1-19 in: Plant Molecular Biology Manual. S. B. Gelvin and R. A. Schilperoort, eds. Kluwer Academic Publishing, Dordrecht, Netherlands.

3. Ausubel, F. M., Brent, R., Kingston, R. E., Moore, D. D., Seidman, J. G., Smith, J. A., and Struhl, K. 1989. Current Protocols in Molecular Biology. John Wiley \& Sons, New York.

4. Best, R. J. 1968. Tomato spotted wilt virus. Adv. Virus Res. 13:65-146.

5. Boerjan, W., Bauw, G., van Montagu, M.,
Inze, D., and Castresana, C. 1994. Distinct phenotypes generated by overexpression and suppression of $S$-adenosyl-L-methione synthetase reveal developmental patterns of gene silencing in tobacco. Plant Cell 6:1401-1414.

6. Chasan, R. 1994. Making sense (suppression) of viral RNA-mediated resistance. Plant Cell 6:1329-1331

7. Clark, M. R., and Adams, A. N. 1977. Characteristics of the microplate method of enzyme-linked immunosorbent assay for the detection of plant viruses. J. Gen. Virol. 34:475-483.

8. Daub, M. E., Jenns, A. E., Urban, L. A., and Brintle, S. C. 1994. Transformation frequency and foreign gene expression in burley and flue-cured cultivars of tobacco. Tob. Sci. 38:51-54.

9. Daub, M. E., Jones, R. K., and Moyer, J. W. 1997. Biotechnological approaches for virus resistance in floral crops. Pages 335-351 in: Biotechnology of Ornamental Plants. R. L. Geneve, J. E. Preece, and S. A. Merkle, eds. $\mathrm{CAB}$ International, Wallingford, Eng.

10. de Avila, A. C., Huguenot, C., de Oliveira Resende, R., Kitajima, E. W., Goldbach, R. W., and Peters, D. 1990. Serological differentiation of 20 isolates of tomato spotted wilt virus. J. Gen. Virol. 71:2801-2807.

11. de Haan, P., Gielen, J. L., Prins, M., Wijkamp, I. G., van Schepen, A., Peters, D., van Grinsven, M. J. Q. M., and Goldbach, R. 1992. Characterization of RNA-mediated resistance to tomato spotted wilt virus in transgenic tobacco plants. Bio/Technology 10:1133-1137.

12. de Haan, P., Wagemakers, L., Peters, D., and Goldbach, R. 1990. The S RNA segment of tomato spotted wilt virus has an ambisense character. J. Gen. Virol. 71:1001-1007.

13. Dons, J. J. M., Mollema, C., Stiekema, W. J., and Visser, B. 1991. Routes to the development of disease resistant ornamentals. Pages 387-417 in: Genetics and Breeding of Ornamental Species. J. Harding, F. Singh, and J. N. M. Mol, eds. Kluwer Academic Publishing, Dordrecht, Netherlands.

14. Fang, G., Hammer, S., and Grumet, R. 1992. A quick and inexpensive method for removing polysaccharides from plant genomic DNA. BioTechniques 13:52-55.

15. Gielen, J. J. L., de Haan, P., Kool, A. J., Peters, D., van Grinsven, M. Q. J. M., and Goldbach, R. W. 1991. Engineered resistance to tomato spotted wilt virus, a negative-strand RNA virus. Bio/Technology 9:1363-1367.

16. Goodwin, J., Chapman, K., Swaney, S., Parks, T. D., Wernsman, E. A., and Dougherty, W. G. 1996. Genetic and biochemical dissection of transgenic RNA-mediated virus resistance. Plant Cell 8:95-105.

17. Gray, S. M., Moyer, J. W., and Kennedy, G. G. 1988. Resistance in Cucumis melo to watermelon mosaic virus 2 correlated with reduced virus movement within leaves. Phytopathology 78:1043-1047.

18. Hausbeck, M. K., Welliver, R. A., Derr, M. A., and Gildow, F. E. 1992. Tomato spotted wilt virus survey among greenhouse ornamentals in Pennsylvania. Plant Dis. 76:795-800.

19. Herrero, S., Faggart, E., Tang, J., Perez, R., and Daub, M. E. 1996. Tobacco cultivars transformed with the nucleocapsid gene of tomato spotted wilt virus express resistance to the virus. (Abstr.) Phytopathology 86:S105.

20. Kim, J. W., Sun, S. S. M., and German, T. L. 1994. Disease resistance in tobacco and tomato plants transformed with the tomato spotted wilt virus nucleocapsid gene. Plant Dis. 78:615-621.

21. Laemmli, U. K. 1970. Cleavage of structural proteins during the assembly of the head of bacteriophage T4. Nature 227:680-685. 
22. Law, M. D., and Moyer, J. W. 1990. A tomato spotted wilt-like virus with a serologically distinct N protein. J. Gen. Virol. 71:933-938.

23. Law, M. D., Speck, J., and Moyer, J. W. 1991. Nucleotide sequence of the $3^{\prime}$ non-coding region and $\mathrm{N}$ gene of the $\mathrm{S}$ RNA of a serologically distinct Tospovirus. J. Gen. Virol. 72:2597-2601.

24. Law, M. D., Speck, J., and Moyer, J. W. 1992. The M RNA of impatiens necrotic spot Tospovirus (Bunyaviridae) has an ambisense genomic organization. Virology 188:732-741.

25. Leary, J. J., Brigati, D. J., and Ward, D. C. 1983. Rapid and sensitive colorimetric method for visualizing biotin labeled DNA probes hybridized to DNA or RNA immobilized on nitrocellulose: Bio-blots. Proc. Natl. Acad. Sci. (USA) 80:4045-4049.

26. Lindbo, J. A., Silva-Rosales, L., Proebsting, W. M., and Dougherty, W. G. 1993. Induction of a highly specific antiviral state in transgenic plants: Implications for regulation of gene expression and virus resistance. Plant Cell 5:1749-1759.

27. MacKenzie, D. J., and Ellis, P. J. 1992. Resistance to tomato spotted wilt virus infection in transgenic tobacco expressing the viral nucleocapsid gene. Mol. Plant-Microbe Interact. 5:34-40.

28. Matteoni, J. A., and Allen, W. R. 1989. Symptomatology of tomato spotted wilt virus infection in florist's chrysanthemum. Can. J. Plant Pathol. 11:373-380.

29. McGarvey, P., and Kaper, J. M. 1991. A simple and rapid method for screening transgenic plants using the PCR. BioTechniques 11:428432.

30. Murashige, T., and Skoog, F. 1962. A revised medium for rapid growth and bioassays with tobacco tissue cultures. Physiol. Plant.
15:473-497.

31. Pang, S. Z., Bock, J. H., Gonsalves, C., Slightom, J. L., and Gonsalves, D. 1994. Resistance of transgenic Nicotiana benthamiana plants to tomato spotted wilt and impatiens necrotic spot tospoviruses: Evidence of involvement of the $\mathrm{N}$ protein and $\mathrm{N}$ gene RNA in resistance. Phytopathology 84:243-249.

32. Pang, S. Z., Jan, F. J., Carney, K., Stout, J., Tricoli, D. M., Quemada, H. D., and Gonsalves, D. 1996. Post-transcriptional transgene silencing and consequent tospovirus resistance in transgenic lettuce are affected by transgene dosage and plant development. Plant J. 9:899-909.

33. Pang, S. Z., Nagpala, P., Wang, M., Slightom, J., and Gonsalves, D. 1992. Resistance to heterologous isolates of tomato spotted wilt virus in transgenic tobacco expressing its nucleocapsid protein gene. Phytopathology 82:1223 1229.

34. Pang, S. Z., Slightom, J. L., and Gonsalves, D. 1993. Different mechanisms protect transgenic tobacco against tomato spotted wilt and impatiens necrotic spot tospoviruses. Bio/ Technology 11:819-824.

35. Peters, D., de Avila, A. C., Kitajima, E. W., de Olieira Resende, R., de Haan, P., and Goldbach, R. 1991. An overview of tomato spotted wilt. Pages 1-14 in: Virus-Thrips-Plant Interactions of Tomato Spotted Wilt Virus. H. Hsu and R. H. Lawson, eds. Proc. USDA Workshop, U.S. Dep. Agric. Agric. Res. Serv., ARS-87.

36. Prins, M., de Haan, P., Luyten, R., van Veller, M., van Grinsven, M. Q. J. M., and Goldbach, R. 1995. Broad resistance to tospoviruses in transgenic tobacco plants expressing three nucleoprotein gene sequences. Mol. PlantMicrobe Interact. 8:85-91.
37. Sherman, J. M., Moyer, J. W., and Daub, M E. 1998. A regeneration and Agrobacteriummediated transformation system for genetically diverse chrysanthemum cultivars. J. Am. Soc. Hortic. Sci. 123:189-194.

38. Smith, H. A., Swanley, S. L., Parks, T. D. Wernsman, E. A., and Dougherty, W. G. 1994. Transgenic plant virus resistance mediated by untranslatable sense RNAs: Expression, regulation, and fate of nonessential RNAs. Plant Cell 6:1441-1453.

39. Ultzen, T., Gielen, J., Venema, F., Westerbroek A, de Haan, P., Tan, M.-L., Schram, A., van Grinsven, M., and Goldbach, R. 1995. Resistance to tomato spotted wilt virus in transgenic tomato hybrids. Euphytica 85:159-168.

40. Urban, L. A., Sherman, J. M., Moyer, J. W. and Daub, M. E. 1994. High frequency shoot regeneration and Agrobacterium-mediated transformation of chrysanthemum (Dendranthema grandiflora). Plant Sci. 98:69-79.

41. Vaira, A. M., Semeria, L., Crespi, S., Lisa, V. Allavena, A., and Accotto, G. P. 1995. Resistance to tospoviruses in Nicotiana benthamiana transformed with the $\mathrm{N}$ gene of tomato spotted wilt virus: Correlation between transgene expression and protection in primary transformants. Mol. Plant-Microbe Interact. 8:66-73.

42. van Wordragen, M. F., de Jong, J., Huitema, H. B. M., and Dons, H. J. M. 1991. Genetic transformation of chrysanthemum using wild type Agrobacterium strains; strain and cultivar specificity. Plant Cell Rep. 9:505-508.

43. Yepes, L. M., Mittak, V., Pang, S., Gonsalves, C., Slightom, J. L., and Gonsalves, D. 1995. Biolistic transformation of chrysanthemum with the nucleocapsid gene of tomato spotted wilt virus. Plant Cell Rep. 14:694-698. 